\title{
PEMETAAN DAERAH RAWAN PENYAKIT DEMAM BERDARAH DENGUE (DBD) DI PULAU BATAM
}

\author{
Arif Roziqin*, Fitri Hasdiyanti* \\ * Politeknik Negeri Batam \\ Geomatics Engineering Study Program \\ Jl. Ahmad Yani, Batam Centre, Batam 29461, Indonesia \\ E-mail: arifroziqin@polibatam.ac.id.
}

\begin{abstract}
Abstrak
Demam Berdarah Dengue (DBD) merupakan penyakit karena virus yang disebarkan oleh nyamuk Aedes Aegypti. Penelitian ini bertujuan untuk memetakan sebaran daerah demam berdarah di Pulau Batam. Penelitian ini menggunakan data sekunder dengan memberikan atribut dan penilaian berdasarkan parameter fisik yang dianggap menyebabkan penyakit demam berdarah. Parameter DBD adalah curah hujan, kelembaban udara dan kepadatan penduduk yang berpengaruh langsung terhadap habitat perkembangan nyamuk Aedes Aegypti. Data yang digunakan adalah data sekunder yang diperoleh dari Badan Pusat Statistik (BPS) Kota Batam tahun 2015. Melalui tahapan penilaian dan analisis data menghasilkan zona tingkat kerawanan. Hasil penelitian menunjukkan bahwa Pulau Batam termasuk daerah dengan tingkat kerawanan rendah. Informasi geospasial yang merupakan sebaran tingkat kerawanan penyakit demam berdarah di Pulau Batam disajikan dalam bentuk peta.
\end{abstract}

\section{Kata kunci : Kerawanan, Demam Berdarah, Informasi Geospasial.}

\begin{abstract}
Dengue Hemorrhagic Fever (DHF) is a viral disease spread by Aedes Aegypti mosquitoes. This study aims to map the distribution of dengue fever areas in Batam Island. This study uses secondary data by providing attributes and scoring based on physical parameters that are considered to cause dengue disease. DHF parameters are rainfall, humidity and population density that directly affect the growth habitat of Aedes Aegypti mosquito. The data used are secondary data obtained from Central Bureau of Statistics (BPS) Batam City 2015. Through the stages of scoring and data analysis yields a zone of vulnerability. The results showed that the island of Batam including areas with low levels of vulnerability. Geospatial information which is the distribution of dengue fever in Batam Island is presented in the form of map.
\end{abstract}

Keywords : Susceptibility, Dengue, Geospatial Information.

\section{Pendahuluan}

Demam Berdarah Dengue (DBD) merupakan salah satu kejadian luar biasa dalam dunia kesehatan di negara Indonesia. DBD juga merupakan penyakit yang dapat mengancam kesehatan masyarakat, upaya pencegahan penyebarannya perlu dilakukan. Sebagai langkah awal untuk pencegahan, maka perlu dilakukan pemetaan. Kota Batam merupakan salah satu daerah di Indonesia yang termasuk rawan DBD. Menurut data yang diperoleh melalui Dinas Kesehatan Kota Batam, tercatat dari seluruh rumah sakit dan puskesmas di Kota Batam yang terus dibanjiri penderita penyakit DBD yang diakibatkan oleh virus dengue. Sebagian besar pasien menjalani rawat inap karena kondisi kritis (Batam Pos, 2016).
Faktor lingkungan berpengaruh besar terhadap peningkatan dan penularan penyakit tular nyamuk seperti DBD. Faktor yang paling berpengaruh diantaranya lingkungan fisik yang terdiri dari curah hujan, kelembaban udara dan kepadatan penduduk. Lingkungan fisik dapat berpengaruh langsung terhadap habitat perkembangbiakan nyamuk yang menjadi asal usul penyebab penyakit DBD (Achmadi dkk, 2010). Geographic Information System (GIS) adalah sebuah rangkaian sistem yang memanfaatkan teknologi digital untuk melakukan analisis spasial (spatial analysis), seperti menganalisa kondisi suatu daerah terhadap penyakit tertentu (Prahasta, 2009). GIS dapat dijadikan sebagai alat bantu yang digunakan untuk memantau kondisi daerah terhadap penyakit DBD. 
GIS juga dirancang untuk memberikan kemudahan penyimpanan data penderita DBD sehingga memudahkan dalam pengidentifikasian dan pencarian. Penyajian akhir dilakukan dengan memanfaatkan GIS yang disajikan dalam bentuk peta (Roziqin, 2016). Penyajian dalam bentuk peta akan lebih memudahkan untuk mengetahui daerah mana yang mengalami kerawanan terhadap penyakit DBD dibandingkan hanya disajikan dalam bentuk tabel ataupun grafik, sehingga perlunya dilakukan pemetaan dan evaluasi spasial vektor penyakit DBD (Roziqin, 2017).

Atas dasar permasalahan penelitian yang telah dikemukakan sebelumnya, maka tujuan dari penelitian ini, yaitu (a) mengetahui parameter fisik untuk menilai tingkat kerawanan wilayah terhadap bahaya DBD di Pulau Batam, (b) mengetahui sebaran kerawanan penyakit DBD dengan tingkat Kecamatan yang ada di Pulau Batam berdasarkan data tahun 2015 .

\section{Metode Penelitian}

\subsection{Desain Penelitian}

Penelitian ini adalah penelitian deskriptifkuantitatif. Data yang digunakan adalah data sekunder yang diperoleh dari instansi terkait.

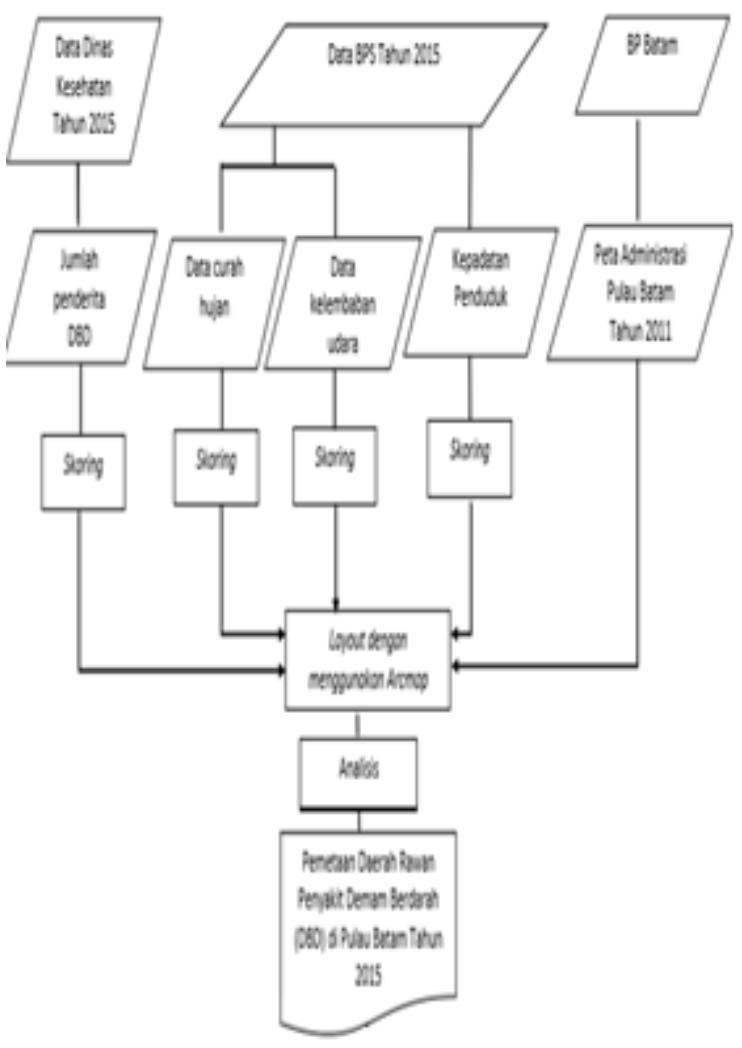

Gambar 1. Diagram Alir Penelitian

\subsection{Lokasi Penelitian}

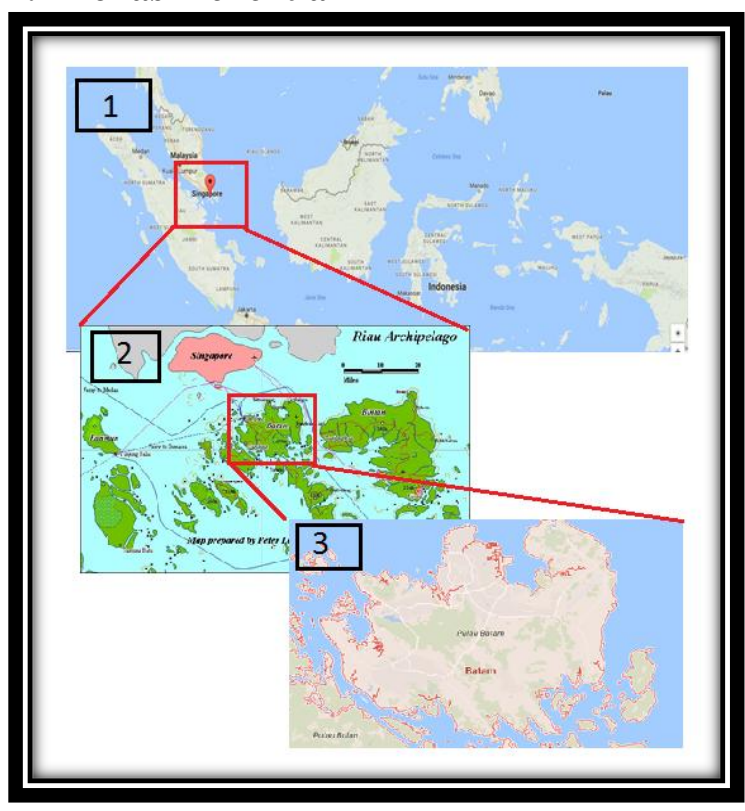

Gambar 2. Lokasi Penelitian

Keterangan:

$1=$ Wilayah Indonesia

2 = Wilayah Kepulauan Riau

3 = Wilayah Pulau Batam

\subsection{Alat dan Bahan}

Adapun alat yang dibutuhkan adalah sebagai berikut:

- $\quad$ Seperangkat Personal Computer (PC)

- Software GIS (Geographic Information System), Microsoft Word, Microsoft Excel.

- Alat tulis: buku, pulpen

Adapun bahan yang dibutuhkan sebagai berikut

- Data sekunder profil Kecamatan 2015 diperoleh dari BPS Kota Batam.

- Data sekunder jumlah penderita DBD Tahun 2015 diperoleh Dinas Kesehatan Kota Batam.

- Shp Pulau Batam Tahun 2011 diperoleh dari Badan Pengusahaan (BP) Batam.

\subsection{Analisis Data}

Penilaian kerawanan DBD dengan memilih parameter yang paling berpengaruh. Penelitian ini hanya menekankan faktor fisik lingkungan dan kependudukan sebagai indikator kerawanan peyakit DBD, tanpa mempertimbangkan aspek sosial dan perilaku masyarakat. Setiap parameter diberikan klasifikasi yang masing-masing diberikan nilai skor, dimana skor 1 untuk kelas rendah, skor 2 untuk kelas sedang dan skor 3 untuk kelas tinggi yang sebelumnya diberikan klasifikasi rentang kelas 
berdasarkan pedoman distribusi frekuensi dan hasil pengolahan dengan GIS. Selanjutnya dilakukan pengolahan atribut di software GIS untuk mencari tingkat kerawanan dan luas kerawanan terhadap parameter curah hujan, kelembaban udara dan kepadatan penduduk untuk menghasilkan peta tingkat kerawanan penyakit DBD di Pulau Batam tahun 2015. Untuk menentukan nilai pada setiap rentang parameter disajikan seperti pada Tabel 1,2 dan 3 .

Tabel 1. Klasifikasi Data Curah Hujan

\begin{tabular}{|l|c|c|}
\hline $\begin{array}{c}\text { Klasifikasi } \\
\text { curah Hujan }\end{array}$ & Skor & Zona \\
\hline $168 \mathrm{~mm} /$ tahun & 1 & Kerawanan tinggi \\
\hline $\begin{array}{l}168.1-168.5 \\
\text { mm/tahun }\end{array}$ & 2 & Kerawanan sedang \\
\hline $\begin{array}{l}168.6-168.8 \\
\text { mm/tahun }\end{array}$ & 3 & Kerawanan rendah \\
\hline
\end{tabular}

Sumber : Analisis Data (2016)

Tabel 2. Klasifikasi Data Kelembaban Udara

\begin{tabular}{|l|c|c|}
\hline $\begin{array}{c}\text { Klasifikasi } \\
\text { Kelembaban } \\
\text { udara }\end{array}$ & Skor & Zona \\
\hline $81.0 \%-81.2 \%$ & 1 & Kerawanan tinggi \\
\hline $81.3 \%$ & 2 & Kerawanan sedang \\
\hline $81.4 \%-81.5 \%$ & 3 & Kerawanan rendah \\
\hline
\end{tabular}

Sumber : Analisis Data (2016)

Tabel 3. Klasifikasi Data Kepadatan Penduduk

\begin{tabular}{|l|c|l|}
\hline $\begin{array}{l}\text { Klasifikasi } \\
\text { Kepadatan } \\
\text { Penduduk }\end{array}$ & Skor & \multicolumn{1}{|c|}{ Zona } \\
\hline $\begin{array}{l}503-1815 \\
\text { jiwa } / \mathrm{km}^{2}\end{array}$ & 1 & Kerawanan tinggi \\
\hline $\begin{array}{l}1816-8248 \\
\text { jiwa/km² }\end{array}$ & 2 & Kerawanan sedang \\
\hline $\begin{array}{l}8249-39041 \\
\text { jiwa/km² }\end{array}$ & 3 & Kerawanan rendah \\
\hline
\end{tabular}

Sumber : Analisis Data (2016)

Berdasarkan tabel klasifikasi data parameter curah hujan, kelembaban udara dan kepadatan penduduk, maka klasifikasi tingkat kerawanan penyakit DBD di Pulau Batam disajikan seperti pada Tabel 4.

Tabel 4 Klasifikasi tingkat kerawanan penyakit DBD

\begin{tabular}{|c|c|c|}
\hline Skor & $\begin{array}{c}\text { Jumlah } \\
\text { Skor }\end{array}$ & Zona \\
\hline 1 & $8-9$ & Kerawanan Tinggi \\
\hline 2 & $4-7$ & Kerawanan Sedang \\
\hline 3 & 3 & Kerawanan Rendah \\
\hline
\end{tabular}

Sumber : Analisis Data (2016)

\section{Hasil dan Pembahasan}

\subsection{Curah Hujan}

Berdasarkan data sekunder, didapatkan data curah hujan di Kecamatan Pulau Batam tahun 2015 disajikan seperti pada Tabel 5.

Tabel 5. Curah Hujan di Kecamatan Pulau Batam

\begin{tabular}{|c|c|c|c|}
\hline No & Kecamatan & Curah Hujan & Skor \\
\hline 1 & Sekupang & $168 \mathrm{~mm} /$ tahun & 1 \\
\hline 2 & Batu Aji & $168.8 \mathrm{~mm} /$ tahun & 3 \\
\hline 3 & Sei Beduk & $168.8 \mathrm{~mm} /$ tahun & 3 \\
\hline 4 & Sagulung & $168.8 \mathrm{~mm} /$ tahun & 3 \\
\hline 5 & Lubuk Baja & $168.8 \mathrm{~mm} /$ tahun & 3 \\
\hline 6 & Batu Ampar & $168.8 \mathrm{~mm} /$ tahun & 3 \\
\hline 7 & Bengkong & $168 \mathrm{~mm} /$ tahun & 1 \\
\hline 8 & Nongsa & $168.8 \mathrm{~mm} /$ tahun & 3 \\
\hline 9 & Batam Kota & $168.5 \mathrm{~mm} /$ tahun & 2 \\
\hline
\end{tabular}

Sumber : BPPS Kota Batam (2015)

Berdasarkan Tabel 5, bahwa sebaran curah hujan di Pulau Batam tahun 2015 tidak terlalu berbeda antar Kecamatan, dimana Kecamatan Sekupang mempunyai curah hujan sebesar $168 \mathrm{~mm} / \mathrm{tahun}$, Kecamatan Batu Aji 168.8 mm/tahun, Kecamatan Sei Beduk $168.8 \mathrm{~mm} /$ tahun, Kecamatan Sagulung $168.8 \mathrm{~mm} /$ tahun, Kecamatan Lubuk Baja 168.8 mm/tahun, Kecamatan Batu Ampar 168.8 $\mathrm{mm} /$ tahun, Kecamatan Bengkong $168 \mathrm{~mm} /$ tahun, Kecamatan Nongsa $168.8 \mathrm{~mm} /$ tahun, Kecamatan Batam Kota $168.5 \mathrm{~mm} /$ tahun dengan jumlah hari hujan 171 yang tersebar di 9 Kecamatan.

Sebaran ini membuat habitat nyamuk Aedes Aegphyti di Pulau Batam hampir sama disetiap Kecamatan dikarenakan kandungan curah hujan yang tersebar hampir merata. Setelah diberikan skor pada masing- masing nilai, maka sebaran curah hujan disajikan seperti pada Gambar 3. 


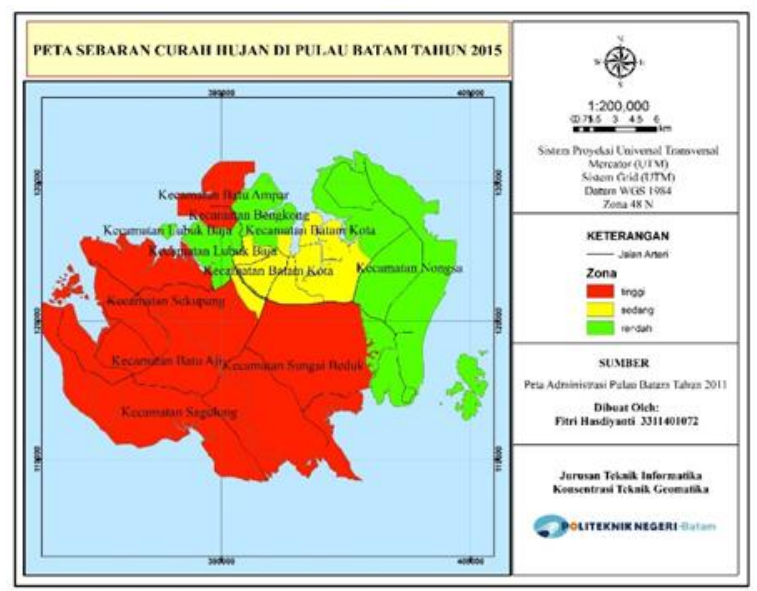

Gambar 3. Sebaran Curah Hujan di Pulau Batam

Berdasarkan gambar 3, dapat dijelaskan bahwa zona sebaran curah hujan di Pulau Batam tahun 2015 dapat diklasifikasikan kedalam zona sebaran curah hujan tinggi yang terdapat di Kecamatan Batu Ampar, Kecamatan Sekupang, kecamatan Batu Aji, Kecamatan Sagulung, Kecamatan Sei Beduk. Zona sebaran curah hujan sedang berada di Kecamatan Batam kota dan zona sebaran curah hujan rendah berada di Kecamatan Nongsa, Kecamatan Bengkong dan Kecamatan Lubuk Baja.

\subsection{Kelembaban Udara}

Berdasarkan data sekunder, didapatkan data kelembaban udara di Kecamatan Pulau Batam tahun 2015 disajikan seperti pada Tabel 6.

Tabel 6. Kelembaban Udara di Pulau Batam Tahun 2015

\begin{tabular}{|c|c|c|c|}
\hline No & Kecamatan & $\begin{array}{c}\text { Kelembaban } \\
\text { Udara }\end{array}$ & Skor \\
\hline 1 & Sekupang & $81.0 \%$ & 1 \\
\hline 2 & Batu Aji & $81.5 \%$ & 3 \\
\hline 3 & Sei Beduk & $81.5 \%$ & 3 \\
\hline 4 & Sagulung & $81.5 \%$ & 3 \\
\hline 5 & Lubuk Baja & $81.0 \%$ & 1 \\
\hline 6 & Batu Ampar & $81.0 \%$ & 1 \\
\hline 7 & Bengkong & $81.5 \%$ & 3 \\
\hline 8 & Nongsa & $81.5 \%$ & 3 \\
\hline 9 & Batam Kota & $81.0 \%$ & 1 \\
\hline
\end{tabular}

Sumber : Analisis Data (2016)

Berdasarkan Tabel 6, bahwa sebaran kelembaban udara di Pulau Batam tahun 2015 tidak terlalu berbeda antar Kecamatan. Dengan kelembaban udara tertinggi berada di Kecamatan Sagulung sebesar 81.5\%, Kecamatan Sei Beduk 81.5\%, Kecamatan Batu Aji 81.5\%, Kecamatan Bengkong $81.5 \%$, dan Kecamatan Nongsa 81.5\%. Hal ini menunjukkan bahwa nyamuk Aedes Aegypti banyak tersebar di Kecamatan dengan angka kelembaban udara yang tinggi. Sedangkan kelembaban udara juga tersebar merata di Kecamatan Sekupang sebesar 81.0\%, Kecamatan Lubuk Baja 81.0\%, Kecamatan Batu Ampar 81.0\%, Kecamatan Batam Kota $81.0 \%$, dengan angka ini tidak menutup kemungkinan tidak adanya nyamuk Aedes Aegypti, tetapi sebarannya lebih rendah dibandingkan dengan angka Kecamatan yang termasuk tinggi sebaran kelembaban udaranya. Setelah diberikan skor pada masing- masing nilai, maka dapat dipetakan seperti Gambar 4.

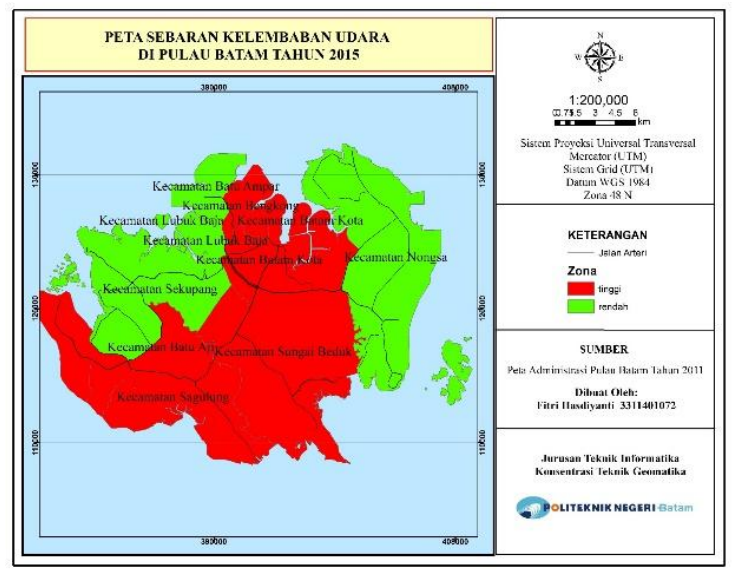

Gambar 4. Sebaran Kelembaban Udara di Pulau Batam

\subsection{Kepadatan Penduduk}

Berdasarkan data sekunder, didapatkan data kepadatan penduduk di Kecamatan Pulau Batam tahun 2015 disajikan seperti pada Tabel 7.

Tabel 7. Kepadatan Penduduk Pulau Batam Tahun 2015

\begin{tabular}{|c|c|c|c|}
\hline No & Kecamatan & $\begin{array}{c}\text { Kepadatan } \\
\text { Penduduk }\end{array}$ & Skor \\
\hline 1 & Sekupang & $1.815 \mathrm{Jiwa} / \mathrm{km}^{2}$ & 1 \\
\hline 2 & Batu Aji & $1.426 \mathrm{Jiwa} / \mathrm{km}^{2}$ & 1 \\
\hline 3 & Sei Beduk & $835 \mathrm{Jiwa} / \mathrm{km}^{2}$ & 1 \\
\hline 4 & Sagulung & $39.041 \mathrm{Jiwa} / \mathrm{km}^{2}$ & 3 \\
\hline 5 & Lubuk Baja & $8.248 \mathrm{~km} / \mathrm{km}^{2}$ & 2 \\
\hline 6 & Batu & $6.565 \mathrm{~km} / \mathrm{km}^{2}$ & 2 \\
\hline 7 & Ampar & & \\
\hline 8 & Nongkong & $7.092 \mathrm{Jiwa} / \mathrm{km}^{2}$ & 2 \\
\hline 9 & Batam Kota & $1.815 \mathrm{jiwa} / \mathrm{km}^{2}$ & 1 \\
\hline
\end{tabular}

Sumber : Analisis Data (2016) 
Berdasarkan Tabel 11, dapat disimpulkan bahwa kepadatan penduduk di Pulau Batam cukup bervariasi. Dimana kepadatan penduduk paling tinggi berada di Kecamatan Sagulung sebesar 39.041 jiwa $/ \mathrm{km}^{2}$. Hal ini bisa menjadi penyebab Kecamatan Sagulung termasuk kedalam tingkat kerawanan tinggi, karena nyamuk Aedes Aegpyti lebih menyukai darah manusia dibandingkan darah yang lainnya dan Kecamatan Sagulung menjadi

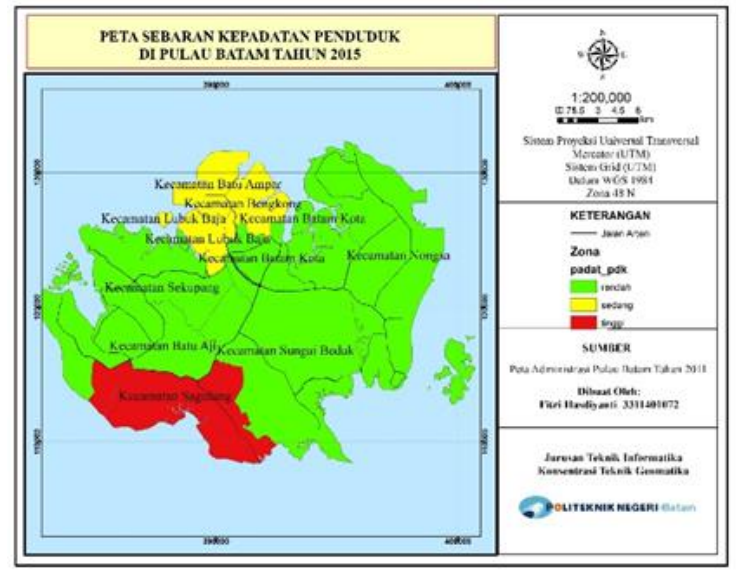

Kecamatan dengan lingkup udara yang sempit sebagai habitat nyamuk Aedes Aegpyti. Setelah diberikan skor pada masing- masing nilai, maka dapat dipetakan seperti Gambar 5.

Gambar 3. Sebaran Zona Kelembaban Udara

\subsection{Sebaran Daerah Rawan DBD}

Penelitian ini menghasilkan peta tematik yang merupakan klasifikasi kerawanan daerah terhadap DBD dengan melihat dan memberikan nilai skor pada setiap parameter yang terkait. Dari hasil scoring dengan pengolahan software GIS, didapatkan 3 kelas klasifikasi tingkat kerawanan, dimana tingkat kerawanan tinggi berada di Kecamatan Batam Kota, Kecamatan Sagulung dan Kecamatan Batu Aji. Tingkat kerawanan sedang berada di Kecamatan Batu Ampar, Kecamatan Bengkong dan Kecamatan Sekupang. Sedangkan tingkat kerawanan rendah berada di Kecamatan Sei Beduk, Kecamatan Lubuk Baja dan kecamatan Nongsa (Gambar 6).

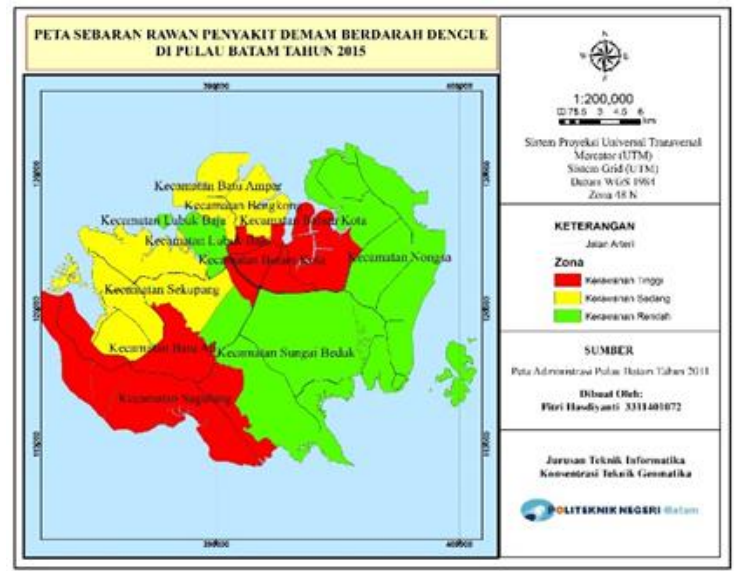

Gambar 4 Peta Sebaran Rawan Penyakit DBD di Pulau Batam

Berdasarkan Gambar 6 mengenai sebaran daerah rawan penyakit demam berdarah di Pulau Batam tingkat kerawanan tinggi terdapat di Kecamatan Batam Kota, Kecamatan Sagulung dan Kecamatan Batu Aji. Kecamatan Batu Aji menurut data sekunder dari Dinas Kesehatan Kota Batam memang banyak kejadian penyakit DBD. Kondisi permukiman di Kecamatan Batu Aji yang sangat padat menjadi salah satu sumber penyebabnya. Untuk permukiman yang padat seharunya dalam pengelolaan kebersihan perlu dilakukan secara baik, terutama kondisi kebersihan saluran air. Secara periodik perlu dilakukan fogging nyamuk demam berdarah di lingkungan permukiman. Luasan klasifikasi rawan DBD di Pulau Batam seperti Tabel 8 dan Gambar 7.

Tabel 8. Luas Zona Kerawanan DBD diPulau Batam Tahun 2015

\begin{tabular}{|c|c|c|}
\hline \multirow{2}{*}{ Zona } & \multicolumn{2}{|c|}{ Luas } \\
\cline { 2 - 3 } & Km & $\%$ \\
\hline Kerawanan Tinggi & 141.8 & $30.81 \%$ \\
\hline Kerawanan Sedang & 101.5 & $22.05 \%$ \\
\hline Kerawanan Rendah & 217 & $47.14 \%$ \\
\hline
\end{tabular}

Sumber : Analisis Data (2016) 


\section{Luas Zona Kerawanan}

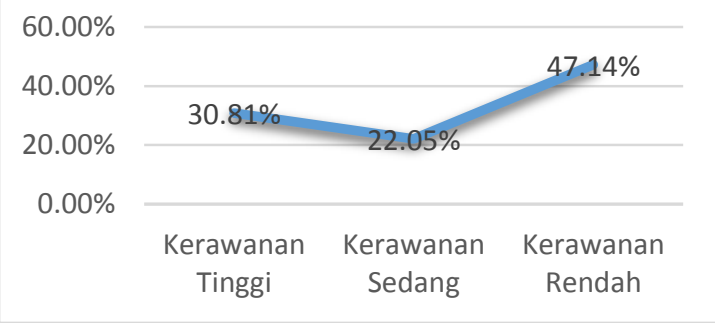

Gambar 5. Grafik Luas Zona Kerawanan DBD di Pulau Batam

Kecamatan Sagulung, Kecamatan Batam Kota dan Kecamatan Batu Aji, tergolong dalam tingkat kerawanan yang tinggi dengan luas sebesar 141.8 $\mathrm{km}$ atau 30.81\%. Kecamatan Batu Ampar, Kecamatan Bengkong dan Kecamatan Sekupang, tergolong dalam tingkat kerawanan yang sedang dengan luas sebesar $101.5 \mathrm{~km}$ atau $22.05 \%$. Sedangkan Kecamatan Nongsa, Kecamatan Lubuk Baja dan Kecamatan Sei Beduk tergolong dalam tingkat kerawanan yang rendah dengan luas sebesar $217 \mathrm{~km}$ atau $47.14 \%$. Hal ini menunjukkan bahwa di Pulau Batam termasuk kedalam wilayah yang rendah sebaran penyakit DBD.

\subsection{Perbandingan Hasil Klasifikasi}

Berdasarkan Tabel 9 dan Gambar 8, menunjukkan bahwa hasil pemetaan dengan parameter fisik, terdapat 2 Kecamatan dari 9 yang tidak sesuai dengan data jumlah penderita yang diperoleh dari Dinas Kesehatan Kota Batam, yaitu Kecamatan Batu aji dan Kecamatan Batu Ampar. Parameter yang digunakan berpengaruh besar terhadap jumlah penderita DBD di Pulau Batam, karena sebagian besar sesuai antara hasil pemetaan dengan kondisi kejadian demam berdarah sebenarnya.

Tabel 9. Perbandingan Tingkat Kerawanan

\begin{tabular}{|c|c|c|c|c|}
\hline Kecamatan & $\begin{array}{c}\text { hasil } \\
\text { klasifikasi } \\
\text { DINKES }\end{array}$ & $\begin{array}{c}\text { hasil } \\
\text { klasifikasi } \\
\text { Peta }\end{array}$ & sesuai & $\begin{array}{c}\text { tidak } \\
\text { sesuai }\end{array}$ \\
\hline Sekupang & sedang & sedang & $\sqrt{ }$ & \\
\hline Batu Aji & sedang & tinggi & & $\sqrt{ }$ \\
\hline Sei Beduk & rendah & rendah & $\sqrt{ }$ & \\
\hline Sagulung & tinggi & tinggi & $\sqrt{ }$ & \\
\hline Lubuk Baja & rendah & rendah & $\sqrt{ }$ & \\
\hline
\end{tabular}

\begin{tabular}{|c|c|c|c|c|}
\hline Batu Ampar & rendah & sedang & & $\sqrt{ }$ \\
\hline Bengkong & sedang & sedang & $\sqrt{ }$ & \\
\hline Nongsa & rendah & rendah & $\sqrt{ }$ & \\
\hline Batam Kota & tinggi & tinggi & $\sqrt{ }$ & \\
\hline
\end{tabular}

Sumber : Analisis Data (2016)

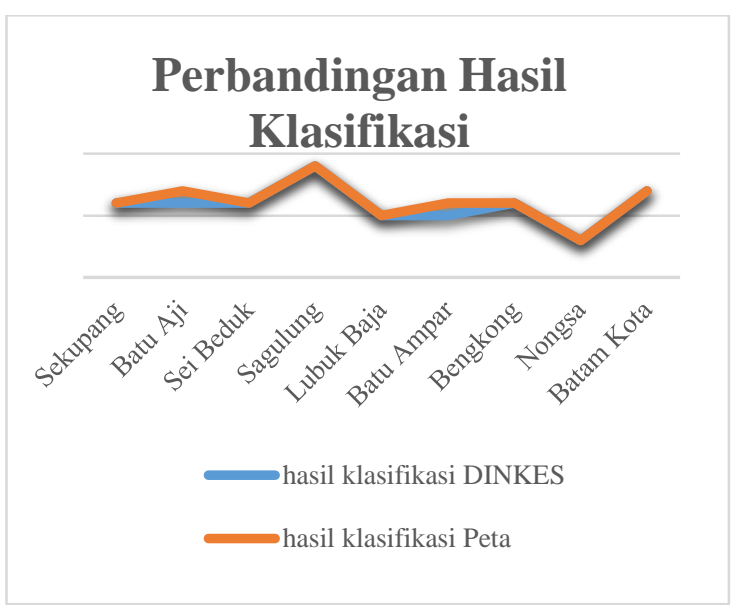

Gambar 6. Grafik Perbandingan Hasil Klasifikasi

\section{Kesimpulan}

Berdasarkan hasil dan pembahasan serta kaitannya untuk mencapai tujuan penelitian, maka dapat disimpulkan, yaitu:

a. hasil pengolahan dengan 3 paramater yaitu, curah hujan, kelembaban udara dan kepadatan penduduk, memiliki keterkaitan dengan penyebab penyakit DBD.

b. tingkat kerawanan untuk penyakit DBD di Pulau Batam termasuk daerah dengan tingkat kerawanan rendah.

c. untuk mendapatkan hasil yang lebih baik, disarankan untuk penelitian selanjutnya agar menambah parameter untuk memetakan sebaran DBD.

\section{Ucapan Terima Kasih}

Penulis mengucapkan terima kasih untuk jajaran Manajemen dan P3M Politeknik Negeri Batam yang telah mendukung iklim kondusif dalam melaksanakan Tri Dharma Perguruan Tinggi. Penulis ucapkan terima kasih kepada Nur Indah Kusumati dan Mahendra Pratama yang membantu dalam proses penelitian ini. Penulis juga perlu mengucapkan terima kasih untuk Mitra Bestari dan Tim Editor Jurnal Integrasi atas dipublikasikannya artikel ini. 


\section{Referensi}

[1] Achmadi U. F., Sukowati S, 2010. Demam Berdarah Dengue. Buletin Jendela Epidemiologi.

[2] Badan Pusat Statistik (BPS). Profil Kecamatan Kota Batam.

[3] Batam Pos, 2016. Korban DBD Meninggal Bertambah, Dinkes Batam Dinilai Gagal,Website:https://suprizaltanjung.wordpre ss.com/2016/02/05/korban-meninggal-

bertambah-dinkes-batam-dinilai-gagal/, diakses tanggal:05 Februari 2016.

[4] Dinas Kesehatan Kota Batam. Jumlah Penderita DBD Tahun 2015.

[5] Kementrian Kesehatan RI. 2007. Waspada Demam Berdarah. Jakarta: Pusat Penanggulangan Krisis Kesehatan Kemenkes RI.

[6] Prahasta, E. 2009. Sistem Informasi Geografis Konsep-konsep Dasar. Bandung: Informatika Bandung.

[7] Roziqin, A. 2016. Pemodelan SIG untuk Kesesuaian Lahan Permukiman Wilayah Pesisir Nongsa di Pulau Batam. Seminar Nasional Teknologi Terapan (SNTT) UGM.

[8] Roziqin, A., Gustin, O. 2017. Pemetaan Perubahan Garis Pantai Menggunakan Citra Penginderaan Jauh di Pulau Batam. Industrial Research Workshop and National Seminar (IRWNS) Politeknik Negeri Bandung.

[9] Roziqin, A., Kusumawati, N.I. 2017. Analisis Pola Permukiman Menggunakan Data Penginderaan Jauh di Pulau Batam. Industrial Research Workshop and National Seminar (IRWNS) Politeknik Negeri Bandung. 